\title{
Local Natural Product Development in the Era of Covid 19 Pandemic
}

\author{
Noval $^{1 *}$, Dyan Fitri Nugraha ${ }^{1}$, Kunti Nastiti ${ }^{1}$, Dahlia Syahrina $^{1}$, Novia $^{1}$ \\ Published online: 5 July 2021
}

\begin{abstract}
Covid-19 is a pandemic disease that infects the respiratory system by cough and sneeze. Covid 19 infection rate in Indonesia is high. On March $2^{\text {nd }}, 2020$, there was reported 2 confirmed cases of Covid-19 infection. Natural ingredients contain a secondary metabolite compound has the potential as an antimicrobial that can be used to kill microorganism as a source of the disease. Natural ingredients that are commonly used as antimicrobials such as bundung, betel leaf and lime peel. Pharmaceutical formulations from natural ingredients need to be made to obtain preparations that are beneficial to the community because they are safer and have minimal side effects. Based on this description, it is necessary to conduct training on the manufacture of pharmaceutical products from natural ingredients or local resources that are easy to make so it can be useful and beneficial for the community during the Covid-19 pandemic. The activities were carried out virtually, followed by the teacher council and students from High School 1 Kahayan Hilir. The activities carried out by providing information related to the efficacy of natural ingredients from local resources, training or workshops on the manufacture of pharmaceutical products and education regarding storing and how to use drugs correctly. This activity is expected to be useful and make a big contribution to the community during the Covid-19 pandemic.
\end{abstract}

Keyword: Pharmaceutical Product, Natural Compound, Covid-19

\section{INTRODUCTION}

Covid-19 is current pandemic disease that spread worldwide, that infect respiratory system by cough and sneeze (Meri et al., 2020). SARS-COV2 is the pathogen, which is part of the coronavirus that also caused SARS in 2003 but is a different type of virus (Budiman et al., 2020). SARS-COV2 first found at the end 2019 in Wuhan, Hubei Province, China (Beiu, Mihai, Popa, Cima \& Popescu, 2020). Signs and symtopms of Covid-19 including acute respiratory such as fever, cough, and hard to breathe. Incubation rate after infection is 5-6 days, 14 days is the longest. At some severe cases, it can cause pneumonia, acute respiratory syndrome, renal failure, and even death (Tosepu et al., 2020).

Indonesia covid-19 infection rate is high, with first confirmed case was happen on March, $2^{\text {nd }}$ 2020 (Tosepu et al., 2020). On March 17 ${ }^{\text {th }}$, 2020, the report said that 172 confirmed cases and 55 deaths occurred. The number is still growing up, on March 29 $9^{\text {th }}, 2020,1.285$ cases was found in 30 provinces. The Covid 19 confirmed case has occurred in Indonesia with the highest provinces are: DKI Jakarta (675), Jawa Barat (149), Banten (106), Jawa Timur (90), dan Jawa Tengah (63) (Tosepu et al., 2020). The confirmed case was going up on March $21^{\text {st }}$ to 1.528 and

${ }^{1}$ Pharmacy Department, Health Faculty, Sari Mulia University, Indonesia

*) corresponding author

Noval

Email: noval@unism.ac.id mortality is 136 (Setiati \& Azwar, 2020).

The spread of Covid-19 cases in South Kalimantan based on data from the South Kalimantan Provincial Health Department on April, 12 ${ }^{\text {nd }} 2020$ there 
were 1,184 Persons Under Monitoring (PUM), 15 Patients Under Investigation (PUI), and 34 Confirmed COVID-19 patients including 28 PUI, 4 patients died, and 2 patients were declared cured. Based on this data, the city of Banjarmasin reported that there were 232 PUM, 7 PUI, 14 Confirmed COVID-19 patients were being treated and 3 patients died. Viruses are very easy to spread and can be transmitted to anyone through direct or indirect contact with sufferers. So that an effective preventive measure is needed in the community to minimize the spread of Covid-19 (Organization, 2020).

Natural ingredients contain a secondary metabolite compound has the potential as an antimicrobial that can be used to kill microorganism that cause disease. According to research by Noval et al., (2019) who conducted a test of antimicrobial activity of the Bundung on E. coli and S.aureus bacteria, it was found that the Bundung plant has the potential as an antimicrobial from the main compound secondary metabolites: flavonoids. Another similar study conducted by Rizkita, A.D (2017) by testing the antimicrobial activity of citronella leaves, green betel and red ginger against mutant Streptococcus bacteria found that each plant had antimicrobial effectiveness with the greatest inhibitory concentration (20\%). Another study was also conducted by Kurniawati, D et al., (2020) who formulated polyherbs of betel leaf, lime peel and bund plants as antiseptics against Staphylococcus aureus. effectiveness as antiseptic with another antiseptic that can be found regularly in the market (Haryono et al., 2021).

Pharmaceutical formulations from natural ingredients need to be made to obtain preparations that are beneficial to the community because they are safer and have minimal side effects (Appriliani et al., n.d). Based on previous research, a formulation and evaluation of mouthwash preparations from the Bundung which is efficacious as an oral antiseptic was made, supported by previous research which stated that the Bundung plant has potential as an antimicrobial (Noval et al., 2020). Bundung are also made into gel formulations based on HPMC which are used as antimicrobials (Noval et al., 2019). Rini's research, A.R.S et al (2017) conducted the formulation of hand sanitizer preparations from pineapple peel extract which has the potential as an anti-bacterium. Other studies have also carried out the formulation of disinfectant preparations from natural ingredients of betel leaf extract added with lime extract has the potential as an antiseptic and natural disinfectant, so this product is useful to minimize the transmission of covid-19 (Budiman et al., 2020).

Based on this description, it is necessary to conduct an easy homemade training on the manufacture of pharmaceutical products from natural ingredients or local so it can be useful and beneficial for the community during the Covid-19 pandemic.

\section{CONCEPTUAL REVIEW}

\section{Literature}

Betel leaf is one of the traditional medicines that is often used as an anti-cancer, adhesive and antiseptic due to the presence of chemical compounds such as saponins, flavonoids, polyphenols and essential oils (Kurniawati D et al., 2020). Lime is also often used as a medicinal plant to relieve coughs, influenza and treat acne. Lime contains various beneficial compounds, namely saponins and flavonoids such as hesperidin, aringin, tangeretin, eriokotrin and eriocitrocid (Kurniawati D et al., 2020).

Another natural ingredient that has the potential as a medicine is bundung, which can be found in all around Kalimantan and is widely empirically used by the community as an antimicrobial. Bundung contains secondary metabolites such as flavonoids, saponins, tannins, phenolics, steroids and terpenoids that have effect as antimicrobials (Noval et al., 2019). Plants or natural materials which have the potential as medicine can be made into pharmaceutical products such as mouthwash, antiseptics, hand sanitizers, cream, gels, hand sanitizers and else. 


\section{Solution and Outcome}

Based on the problems faced by community, the solutions offered by the proposer through community service activities regarding the Development of Natural Ingredients-Based Pharmaceutical Products or Local Wealth in the Covid-19 Pandemic (Noval et al., 2020), include:

2.1 Provide information related to the efficacy and function of natural materials or local resources that have the potential as medicine that can be utilized and useful during the Covid-19 pandemic.

2.2 Provide training or workshops related to the manufacture of pharmaceutical products such as mouthwash, hand sanitizer, cream, gel, hand sanitizer or other products from natural ingredients or local wealth to the community that can be used and beneficial during the Covid-19 pandemic.

2.3 Provide education on the proper use and storage of pharmaceutical products from natural ingredients or local resources to the public.

3. Target

The targets that need to be achieved through this community service are as follows:

3.1 Increasing public knowledge regarding the efficacy and function of natural ingredients or local resources that have the potential as medicine to be utilized and used during the Covid19 pandemic.

3.2 The community is able to make their own pharmaceutical products from natural ingredients or local resources that can be used during the Covid-19 pandemic.

3.3 Increase the knowledge and understanding of the community regarding the correct use and storage of pharmaceutical products from natural ingredients or local resources.

\section{Output}

The expected outputs through this community service activity are as follows:

4.1 Produce pharmaceutical products from natural ingredients or local resources that are licensed by the Ministry of Health and BPOM.

4.2 The pharmaceutical products may be patented.

\section{RESEARCH DESIGN}

Description of Activities in Implementing Solutions to Community Problems

The activity of developing pharmaceutical products based on natural ingredients from local resources have been carried out virtually in February - June 2021 by the activity committee, namely lecturers and students of Sari Mulia University as well as partners and participants involved, namely the teacher council and students from High School 1 Kahayan Hilir . Community service activities begin with the preparation of information materials that will be used in activities such as power points, brochures, leaflets, posters and so on. Furthermore, the preparation of tools and materials for training activities on the manufacture of pharmaceutical products will be made during training or workshops. Before giving the information, participants did a pretest to find out how far the community's knowledge about the efficacy and function of natural materials or local wealth was. After the participants finished working on the pretest questions, the first activity was carried out, namely providing information regarding the efficacy and function of natural materials or local resources that have the potential as drugs in the hope of increasing public knowledge about the properties and functions of natural ingredients that can be used during the Covid-19 pandemic. 
Table 1 Plans for implementing community service to solving community problems

\begin{tabular}{|c|c|c|c|}
\hline No. & Problems & Solutions & Recent Condition \\
\hline 1 & $\begin{array}{l}\text { The case of the Covid-19 pandemic } \\
\text { continues to increase, making it } \\
\text { difficult for people to get } \\
\text { pharmaceutical products because of } \\
\text { the increasingly soaring selling } \\
\text { prices, besides there are still many } \\
\text { natural ingredients or local } \\
\text { resources that have the potential as } \\
\text { drugs but not been used as } \\
\text { pharmaceutical products that are } \\
\text { beneficial to the community, } \\
\text { especially during the Covid-19 } \\
\text { pandemic } 19 \text {. }\end{array}$ & $\begin{array}{l}\text { Providing information related to } \\
\text { the efficacy and function of natural } \\
\text { ingredients or local resources that } \\
\text { have the potential as medicine, } \\
\text { training or workshops related to the } \\
\text { manufacture of pharmaceutical } \\
\text { products from natural ingredients } \\
\text { or local resources to the } \\
\text { community. }\end{array}$ & $\begin{array}{l}\text { Pharmaceutical products from } \\
\text { natural ingredients or local wealth } \\
\text { that have the potential as } \\
\text { medicines are very useful for the } \\
\text { community during the Covid-19 } \\
\text { pandemic, and people are able to } \\
\text { make their own pharmaceutical } \\
\text { products from natural ingredients } \\
\text { or local resources that have the } \\
\text { potential as drugs. }\end{array}$ \\
\hline 2 & $\begin{array}{l}\text { Lack of public knowledge about } \\
\text { how to use and store } \\
\text { pharmaceutical products correctly. }\end{array}$ & $\begin{array}{l}\text { Provide education regarding the } \\
\text { correct use and storage of } \\
\text { pharmaceutical products from } \\
\text { natural ingredients or local } \\
\text { resources to the community }\end{array}$ & $\begin{array}{l}\text { The community understands how } \\
\text { to use and store pharmaceutical } \\
\text { products from natural ingredients } \\
\text { or local resources correctly. }\end{array}$ \\
\hline
\end{tabular}

The second activity was training or workshops on the manufacture of pharmaceutical products from natural ingredients or local resources such as mouthwash, hand sanitizers, creams, gels, or other products. Furthermore, education is provided regarding the correct use and storage of pharmaceutical products from natural ingredients or local resources. The activity ended with participants working on posttest to measure the knowledge and understanding of the community after providing information related to the efficacy and function of natural ingredients that have the potential as medicines, training or workshops on the manufacture of pharmaceutical products from natural ingredients as well as education on how to use and store the pharmaceutical products.

\section{RESULTS AND DISCUSSION}

Covid is a disease that is pandemic in the world, this disease is caused by a virus that attacks the respiratory tract. Natural ingredients contain chemical compounds that have the potential to kill disease-causing microorganism, especially natural ingredients from local resources. These natural ingredients need to be made into a dosage formulation to deliver their efficacious compounds to be of benefit to society at large during the Covid-19 pandemic. The implementation of this community service aimed to provide information, education and training on the manufacture of pharmaceutical products from natural ingredients or local resources that are easy to make so that they can be useful and beneficial to the community during the Covid-19 pandemic.

Analysis of the problem that the Covid-19 case continues to increase so that provisions are needed for the community to protect themselves from Covid-19, it is the community's need to always remain clean and maintain personal and environmental hygiene. In addition, the increasing selling price of pharmaceutical products makes it difficult to obtain, especially for the poor, who difficult to buy. The large number of natural ingredients or local wealth in the South Kalimantan area has not been used as a pharmaceutical product that is useful for the community during the Covid-19 pandemic.

The implementation of community service is certainly very facilitated by the partners involved so that these activities can be carried out as expected. The activities was carried out in February 2021: first activity was giving out pretest to find out the community's knowledge about the efficacy and function of natural materials or local wealth, before being given information related to the efficacy and function of natural materials or local wealth. Then, we were providing information related to the 
efficacy and function of natural ingredients or local resources that have the potential as drugs that can be utilized and useful during the Covid-19 pandemic, followed by training or workshops related to the manufacture of pharmaceutical products such as mouthwash, hand sanitizer, cream, gel, hand sanitizer or other products as well as providing education on the correct use and storage of its products.

The activity ended with the provision of posttest to measure the knowledge and understanding of the community after providing information regarding the efficacy and function of natural materials that have the potential as drugs, training or workshops on the manufacture of pharmaceutical products from natural ingredients and education on how to use and store pharmaceutical products from natural ingredients local wealth. The implementation of community service was running smoothly so that these activities can benefit the community and everyone else.

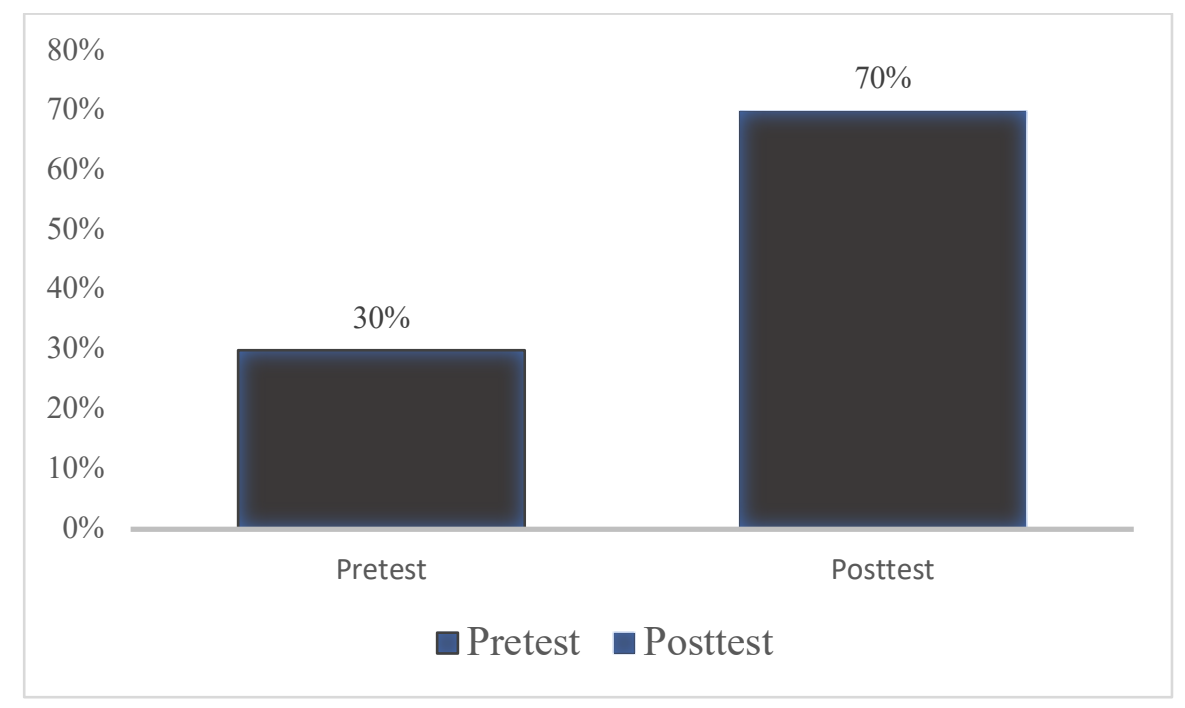

Figure 1. Understanding Level

Based on Figure 1 above, the results of the percentage level of understanding of the pretest are $30 \%$ and the posttest are $70 \%$. The results obtained are based on the participants' understanding after we provided information and delivered training or workshops. The questions given to measure the level of understanding of the participants in the pretest and posttest which were 10 questions. The results then evaluated, and it was found that there was an increase in the level of understanding between before and after we were providing information and workshops. It was seen from the results of the pretest and posttest that had been carried out. Based on the results of increasing understanding of community service activities, we hope that respondents are able to produce pharmaceutical products from natural ingredients or local resources that get distribution permits from the Ministry of Health and BPOM as well as pharmaceutical products from natural ingredients or local resources that can be patented and can be developed to increase economic value for the community.

\section{CONCLUSIONS}

Community service activities are carried out smoothly with the involvement and contribution of High School 1 Kahayan Hilir partners. The provision of information, education and training or workshops on the manufacture of pharmaceutical products from natural ingredients as well as education on how to use and store pharmaceutical products from natural materials or local resources are expected to be useful and make a major contribution to the community during the Covid-19 pandemic. 


\section{Conflict of Interests}

The authors declared that no potential conflicts of interests with respect to the authorship and publication of this article.

\section{REFERENCES}

Achmad, S. A. (1989) Buku Materi Pokok Kimia Organik Bahan Alam. Edited by Universitas Terbuka. Jakarta: Depdikbud.

Appriliani, A., Suganda, A.G \& Hartati, R. (2018). Inhibition test of tyrosinase activity from Zingiberaceae. Jurnal Ilmiah Farmasi, 14 (1).

Beiu., Mihai., Popa., Cima \& Popescu. (2020). Frequent hand washing for covid-19 prevention can cause hand dermatitis : manajemen tips. Cureus Publishing Beyond Open Access v. 12 (4).

Budiman I., Bastoni., Sari E.N., Hadi E.E., Asmaliyah., Siahaan, A., Januar, R., Hapsari, R.D. (2020). Progress of paludiculture projects in supporting peatland ecosystem restoration in Indonesia. Global Ecology dan Conservation 23.

D. Kurniawati, N. Noval, and K. Nastiti, "Potensi Antiseptik Poliherbal Daun Sirih (Piper Betle), Kulit Jeruk Nipis (Citrus aurantifolia) dan Tanaman Bundung (Actinuscirpus grossus) pada Tindakan Keperawatan dan Kebidanan," Din. Kesehat. J. Kebidanan Dan Keperawatan, vol. 11, no. 1, pp. 420-431, 2020, doi: 10.33859/dksm.v11i1.552.

Friska, A. R., Haniastuti, T. and Utami, T. W. (2016) 'Skrining Fitokimia dan Aktivitas Antibakteri ekstrak etanol daun sirsak (Annona muricata, L) pada Streptococcus mutans ATCC 35688'

Harbone, J. B. (1987) Metode Fitokimia. Penuntut Cara Modern Menganalisis Tumbuhan. Terjemahan K. Padmawinata \& I. Soediro. Bandung: ITB.

Haryono, I. A., Noval, N., \& Nugraha, B. (2021). Formulasi Buah Tampoi (Baccaurea macrocarpa) dalam Sediaan Masker Gel sebagai Antiaging. Jurnal Surya Medika (JSM), 6(2), 102-110. https://doi.org/10.33084/jsm.v6i2.2126.

Jawetz, M. and Aldeberg (2007) Mikrobiologi Kedokteran. 23rd edn. Jakarta.

Meri et al., (2020). Pemberdayaan masyarakat dalam penggunaan handsanitiser dan masker sebagai upaya preventif terhadap covid-19. Bantenese Jurnal Pengabdian Masyarakat, Volume 2 nomor 1.

Noval, N., Yuwindry, I., \& Syahrina, D. (2019). Phytochemical Screening and Antimicrobial Activity of Bundung Plants Extract by Dilution Method. Jurnal Surya Medika. https://doi.org/10.33084/jsm.v5i1.954.

Noval, N., Nastiti, K., Nugraha, D. F., Rahmadani, R., \& Alawiyah, T. (2020). Produk Inovasi Hand Sanitizer dari Akar Bajakah Sebagai Upaya Pencegahan di Masa Pandemi Covid-19. LOGISTAJurnal Ilmiah Pengabdian Kepada Masyarakat, 4(2), 305-312.

Noval, N., \& Raihana, R. (2019). Efek Ekstrak Etanol Akar Pasak Bumi (Eurycoma Longifolia, Jack) terhadap Ekspresi HRAS pada Organ Hati Tikus Galur Sprague Dawley pada Pemberian Doxorubicin. Jurnal Surya Medika (JSM), 5(1), 115-130. https://doi.org/10.33084/jsm.v5i1.952

Noval, Noval, Melviani Melviani, Novia Novia, and Dahlia Syahrina. 2020. "Formulasi Dan Evaluasi Sediaan Obat Kumur (Mouthwash) Dari Ekstrak Etanol Tanaman Bundung (Actinoscirpus Grossus) Sebagai Antiseptik Mulut". Jurnal Surya Medika (JSM) 6 (1), 112-20. https://doi.org/10.33084/jsm.v6i1.1626. 
Noval, N., Rosyifa, R., \& Annisa, A. (2020). Effect of HPMC Concentration Variation as Gelling Agent on Physical Stability of Formulation Gel Ethanol Extract Bundung Plants (Actinuscirpus Grossus). https://doi.org/10.4108/eai.23-11-2019.2298326

Noval, N., Appriliani, R., \& Oktaviannoor, H. (2021). Evaluasi Pengaruh Konsentrasi Pati Biji Cempedak (Artocarpus champeden) sebagai Bahan Pengisi pada Formulasi Tablet Paracetamol. Jurnal Surya Medika $\quad$ (JSM), 6(2), 111-118. https://doi.org/10.33084/jsm.v6i2.2127.

Organization, W. H. (2020). Rational use of personal protective equipment (PPE) for coronavirus disease (COVID-19). March.

R. N. Putri, "Indonesia dalam Menghadapi Pandemi Covid-19," J. Ilm. Univ. Batanghari Jambi, vol. 20, no. 2, p. 705, 2020, doi: 10.33087/jiubj.v20i2.1010.

Rini, A.R.S., Supartono \& Wijayati, N. (2017). Handsanitizer ekstrak kulit nanas sebagai antibakteri Staphylococcus aureus dan Eschericia coli. Indonesian Journal of Chemical Science, 6 (1).

Rizkita, A.D. (2017). Efektivitas Antibakteri Ekstrak Daun Sereh Wangi, Sirih Hijau, dan Jahe Merah terhadap Pertumbuhan Streptococcus Mutans. Prosiding Seminar Nasional Sains dan Teknologi, ISSN : 2407-1846.

Sari, P. F. (2017) Efektivitas Mendong Sebagai Bioremediator Tanah Sawah Tercemar Kromium Oleh Limbah Industri. Universitas Sebelas Maret.

Setiati, S., Azwar, M.K. (2020). Covid-19 and Indonesia. The Indonesian Journal of Internal Medicine, Vol. 52 no. 1.

Tosepu, R., Gunawan, J., Effendy, D. S., Ode, L., Ahmad, A. I., Lestari, H., Bahar, H., \& Asfian, P. (2020). Journal Pre of. Science of the Total Environment, 138436. https://doi.org/10.1016/j.scitotenv.2020.138436 


\section{Appendix}
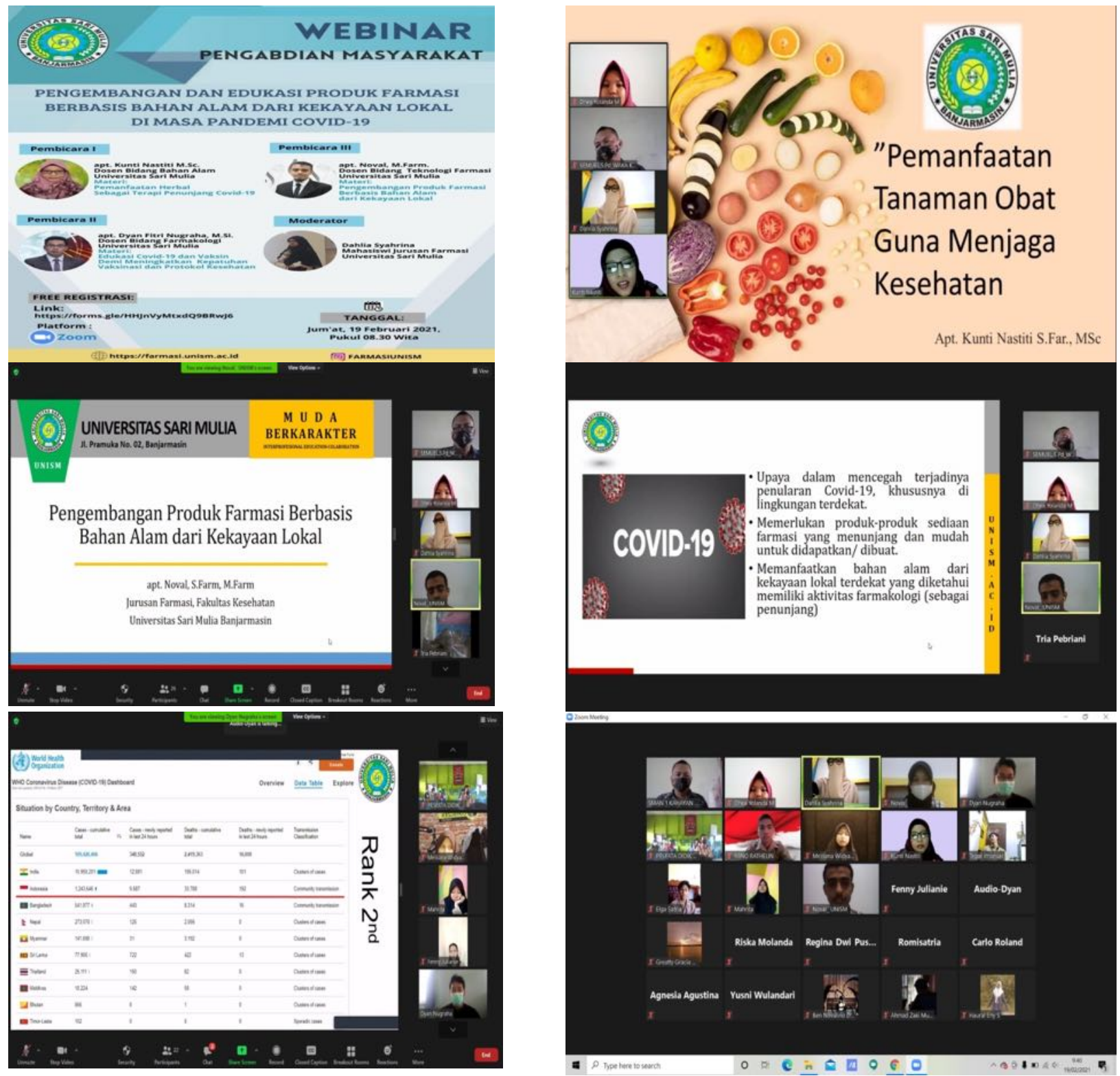